\title{
ULTRAVIOLET SPECTROPHOTOMETRIC METHOD DEVELOPMENT FOR ESTIMATION OF NEW ANTIVIRAL REPURPOSING DRUG FAVIPIRAVIR
}

\author{
JEEVANA JYOTHI B*, VENKATA KAVYA R \\ Department of Pharmaceutics, Institute of Pharmaceutical Technology, Sri Padmavati Mahila Visvavidyalayam (Women's University), \\ Tirupati, Andhra Pradesh, India. Email: jeevanajyothib8@gmail.com
}

Received: 20 April 2021, Revised and Accepted: 28 May 2021

\section{ABSTRACT}

Objective: A new, economical, precise, linear, sensitive, accurate, ultraviolet (UV) spectrophotometric method for the estimation of new antiviral repurposing drug favipiravir as there is no reported simple UV spectrophotometric method for estimation. The efforts were made for development and validation of favipiravir as per ICH guidelines, because drug has a wide scope for formulations to be developed for treating different viruses.

Methods: This method was developed using ethanol and water as a solvent. Favipiravir showed the absorption maxima at 234 nm. A Shimadzu UV-visible spectrophotometer (UV JAPAN 1801) was used to carry out spectral analysis.

Results: The developed method was linear for a range of $0-10 \mu \mathrm{g} / \mathrm{ml}$ and displayed a good correlation coefficient of 0.9995 . Accuracy of the method was estimated using a recovery study. The amount of drug recovered was found to be in the range of $99.30-99.91 \%$. The \% relative standard deviation value of intraday precision was found to be $0.408 \%$ and interday precision was found to be in the range of $0.348-0.693 \%$. The $\%$ relative standard deviation found to be $<2$ which are indicative of the precision and reproducibility of the method. Detection limit and quantitation limit were noticed as 0.095 and 0.290 , respectively.

Conclusion: The developed UV spectrophotometric method was validated statistically for linearity, accuracy, precision, and sensitivity and results proved that the method can be employed for routine analysis of favipiravir.

Keywords: Favipiravir, Ultraviolet spectrophotometric method, Linearity, Relative standard deviation.

(C) 2021 The Authors. Published by Innovare Academic Sciences Pvt Ltd. This is an open access article under the CC BY license (http://creativecommons.org/ licenses/by/4.0/) DOI: http://dx.doi.org/10.22159/ajpcr.2021v14i7.41966. Journal homepage: https://innovareacademics.in/journals/index.php/ajpcr

\section{INTRODUCTION}

Favipiravir is a prodrug derived by chemical modification of the pyrazine moiety of T-1105. Favipiravir is quickly emerging as the top choice for COVID-19 treatment due to the absence of definitive treatment and a lot of emphasis on repurposing of existing drugs because developing a new drug would take years. Favipiravir (Fig. 1) is emerging as repurposing drug for the treatment of novel viruses. Toyama Chemicals, Japan, initially developed favipiravir for treating influenza. Chemically, it is 5-fluoro-2-oxo-1H-pyrazine-3-carboxamide [1].

Favipiravir is a viral RNA polymerase inhibitor which prevents replication of the viral genome. RNA polymerase is the enzyme which is essential for the virus to make copies of itself in the body. It selectively targets this enzyme, to inhibit the replication of the virus in the body [2].

Literature survey revealed that there were no simple ultraviolet (UV) spectrophotometric methods for favipiravir. Efforts were made for development and validation of favipiravir as per ICH guidelines. Favipiravir is effective antiviral drug and has a wide scope for formulations to be developed for treating different viruses.

\section{METHODS}

UV-visible spectrophotometer Shimadzu UV JAPAN 1801, electronic balance, Sonicator. Favipiravir is obtained as a gift sample from INCHEM Laboratories Pvt. Ltd., Hyderabad, India.

Development of UV spectrophotometric method for the estimation of favipiravir

Favipiravir with aqueous solvents produced no absorbance due to its poor solubility. Absorbance was produced with non-aqueous solvents [3]. In this method, absorbance was produced when favipiravir was first dissolved with non-aqueous solvent ethanol and made up to the volume with aqueous solvent water. Hence, water with ethanol was used as cosolvent for UV estimation of favipiravir.

Preparation of standard stock and working standard solutions Accurately weighed $100 \mathrm{mg}$ of favipiravir was transferred to a standard flask. Five milliliters of ethanol was added, sonicated and then volume was made up to $100 \mathrm{ml}$ with water to give a solution $1 \mathrm{mg} / \mathrm{ml}$. This solution is labeled as standard stock solution. From the standard stock solution, $10 \mathrm{ml}$ was pipetted out into a $100 \mathrm{ml}$ volumetric flask and diluted up to mark with distilled water to yield a solution of strength $100 \mu \mathrm{g} / \mathrm{ml}$. This solution was labeled as working standard solution [4].

\section{Determination of absorption maxima $\left(\lambda_{\max }\right)$ of favipiravir}

From working standard solution, $1 \mathrm{ml}$ was pipetted out into a $100 \mathrm{ml}$ volumetric flask and diluted up to mark with distilled water to yield a solution of strength $10 \mu \mathrm{g} / \mathrm{ml}$. The spectrum of this solution was scanned over 200-400 nm range in a UV spectrophotometer against distilled water as blank to estimate the absorption maxima $\left(\lambda_{\max }\right)$ of favipiravir.

\section{Validation of proposed UV spectrophotometric method} UV spectrophotometric method was validated statistically for the following parameters.

\section{Linearity}

The linearity of the developed method was established by preparing fresh aliquots from working standard solution. Subsequent dilutions were made to produce concentration range $2-10 \mu \mathrm{g} / \mathrm{ml}$ by taking aliquots of $0.2,0.4,0.6,0.8$, and $1.0 \mathrm{ml}$ to series of $10 \mathrm{ml}$ volumetric flasks from working standard solution and diluted with distilled water. 
Absorbance was recorded in triplicate for each concentration at $234 \mathrm{~nm}$ using distilled water as blank. Calibration curve was plotted by taking concentration on X-axis and absorbance on Y-axis [5].

\section{Precision}

Precision is a measure of the agreement among the values obtained when the same solution is repeatedly assayed. Repeatability also termed as intraday precision was obtained by evaluating the absorbance of six replicates of working standard solution $10 \mu \mathrm{g} / \mathrm{ml}$ of favipiravir on a single day. Interday precision was calculated in three different days at different time intervals. The \% relative standard deviation (\% RSD) serves as a measure of precision $[6,7]$.

\section{Accuracy}

Standard addition method was employed to determine the accuracy of proposed UV spectrophotometric method. To $10 \mu \mathrm{g} / \mathrm{ml}$ of pre-analyzed sample solution, a known amount of favipiravir was added to yield a solution of concentration range 15,20 , and $25 \mu \mathrm{g} / \mathrm{ml}$. In triplicate, absorbance was recorded and percentage recovery was calculated $[8,9]$.

\section{Detection limit and quantitation limit}

Using the calibration curve, detection limit and quantitation limit for favipiravir can be determined [10]. The formulas used to measure are as follows:

\section{Detection limit $=3.3 \times \mathrm{S}$ D/Slope}

Quantitation Limit $=10 \times$ S D $/$ Slope

Where,

S.D = Standard deviation of response of least concentration of the calibration curve

\section{$\mathrm{S}=$ Slope of calibration curve}

\section{RESULTS}

Absorption maxima $\left(\lambda_{\max }\right)$ of favipiravir

The $\lambda$ of favipiravir was found to be $234 \mathrm{~nm}$ (Fig. 2). Hence, reported $\lambda_{\text {max }}$ of favipiravir was $234 \mathrm{~nm}$.<smiles>NC(=O)c1nc(F)cnc1O</smiles>

Fig. 1: Chemical structure of favipiravir

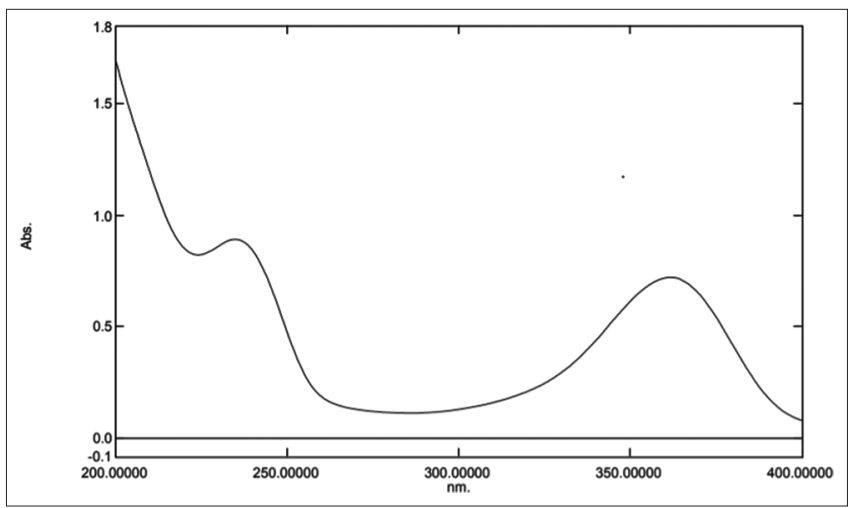

Fig. 2: $\lambda \max$ of favipiravir in distilled water at $234 \mathrm{~nm}$
Linearity

The results obtained for the linearity of favipiravir are presented in Table 1. Calibration curve of favipiravir is unveiled in Fig. 3; it was evident that favipiravir obeys Beer's Lambert law with the concentration range of $0-10 \mu \mathrm{g} / \mathrm{ml}$ having line equation $\mathrm{y}=0.0853 \mathrm{x}$ +0.0089 with a correlation coefficient of 0.9995 which was very close to unity indicating positive correlation between concentrations of favipiravir.

\section{Precision}

Intraday and interday precision results are provided in Tables 2 and 3. RSD value of intraday precision was found to be $0.408 \%$ and interday precision was found to be in the range of $0.348-0.693 \%$. RSD values obtained were within the acceptable limit, that is, RSD $<2 \%$ which indicates that the developed method was precise with repeatability.

\section{Accuracy}

Accuracy results obtained by mean \% recovery are presented in Table 4 which were acceptable which means that the established method was accurate.

\section{Detection Limit and Quantitation Limit}

Detection limit and quantitation limit of favipiravir were found to be $0.095 \mu \mathrm{g} / \mathrm{ml}$ and $0.290 \mu \mathrm{g} / \mathrm{ml}$, respectively, indicating the sensitivity of above method (Table 5)

\section{DISCUSSION}

The spectrum of $10 \mu \mathrm{g} / \mathrm{ml}$ of favipiravir is shown in Fig. 2 indicated peak absorbance at $234 \mathrm{~nm}$. Hence, $234 \mathrm{~nm}$ was considered as

Table 1: Concentration versus absorbance values for the estimation of favipiravir

\begin{tabular}{|c|c|c|}
\hline $\begin{array}{l}\text { Concentration of } \\
\text { favipiravir }(\mu \mathrm{g} / \mathrm{ml})\end{array}$ & Absorbance $n=3 \pm s d$ & RSD (\%) \\
\hline 0 & 0 & 0 \\
\hline 2 & $0.198 \pm 0.0025$ & 1.262 \\
\hline 4 & $0.344 \pm 0.0028$ & 0.813 \\
\hline 6 & $0.524 \pm 0.0076$ & 1.450 \\
\hline 8 & $0.693 \pm 0.0097$ & 1.399 \\
\hline 10 & $0.857 \pm 0.0110$ & 1.283 \\
\hline
\end{tabular}

RSD: Relative standard deviation

Table 2: Repeatability or intraday precision results for favipiravir

\begin{tabular}{lll}
\hline Concentration $(\mu \mathrm{g} / \mathrm{ml})$ & Absorbance & RSD (\%) \\
\hline 10 & 0.859 & 0.408 \\
& 0.862 & \\
& 0.856 & \\
& 0.860 & \\
& 0.852 & \\
& 0.857 & \\
\hline
\end{tabular}

RSD: Relative standard deviation

Table 3: Interday precision results for favipiravir

\begin{tabular}{lll}
\hline Day & Absorbance & RSD (\%) \\
\hline Day 1 & 0.872 & 0.693 \\
& 0.863 & \\
Day 2 & 0.859 & 0.463 \\
& 0.865 & \\
Day 3 & 0.858 & 0.348 \\
& 0.867 & \\
\hline
\end{tabular}

RSD: Relative standard deviation 


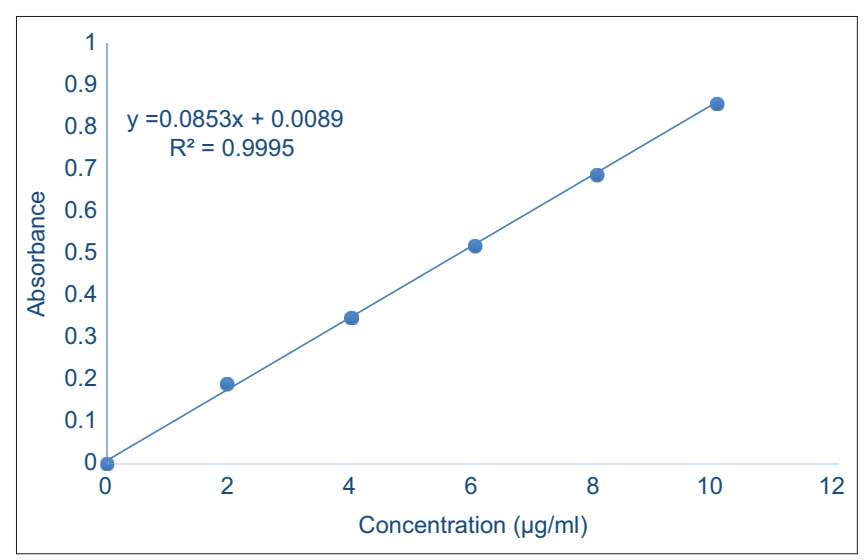

Fig. 3: Calibration curve for the estimation of favipiravir

Table 4: Accuracy results for favipiravir

\begin{tabular}{lllll}
\hline $\begin{array}{l}\text { Amount } \\
\text { of sample } \\
(\boldsymbol{\mu g} / \mathbf{m l})\end{array}$ & $\begin{array}{l}\text { Amount of } \\
\text { drug added } \\
(\boldsymbol{\mu g} / \mathbf{m l})\end{array}$ & $\begin{array}{l}\text { Amount } \\
\text { recovered } \\
(\boldsymbol{\mu g} / \mathbf{m l})\end{array}$ & $\begin{array}{l}\% \\
\text { recovered }\end{array}$ & $\begin{array}{l}\text { Mean \% } \\
\text { recovered }\end{array}$ \\
\hline 10 & 5 & 14.94 & 99.60 & 99.42 \\
& 5 & 14.88 & 99.20 & \\
10 & 5 & 14.92 & 99.46 & \\
& 10 & 20.10 & 100.5 & 99.91 \\
& 10 & 19.89 & 99.45 & \\
10 & 10 & 19.96 & 99.80 & \\
& 15 & 24.80 & 99.2 & 99.30 \\
& 15 & 24.92 & 99.68 & \\
\hline
\end{tabular}

Table 5: Detection limit and quantitation limit results for favipiravir

\begin{tabular}{ll}
\hline Detection limit & $0.095 \mu \mathrm{g} / \mathrm{ml}$ \\
Quantitation limit & $0.290 \mu \mathrm{g} / \mathrm{ml}$ \\
\hline
\end{tabular}

Table 6: Findings of favipiravir

\begin{tabular}{ll}
\hline Parameters & Findings of favipiravir \\
\hline Working $\lambda_{\text {max }}(\mathrm{nm})$ & $234 \mathrm{~nm}$ \\
Beer's law limit $(\mu \mathrm{g} / \mathrm{ml})$ & $0-10 \mu \mathrm{g} / \mathrm{ml}$ \\
Regression equation & $\mathrm{y}=0.0853 \mathrm{x}+0.0089$ \\
Correlation coefficient & 0.9995 \\
Intercept & 0.0089 \\
Slope & 0.0853 \\
Intraday precision & $0.408 \%$ \\
Interday precision & $0.348-0.693 \%$ \\
Accuracy & $99.30-99.91 \%$ \\
Detection limit & $0.095 \mu \mathrm{g} / \mathrm{ml}$ \\
Quantitation limit & $0.290 \mu \mathrm{g} / \mathrm{ml}$ \\
\hline
\end{tabular}

absorption maxima, $\lambda_{\max }$. The results of concentrations of favipiravir and the corresponding absorbances are shown in (Table 1) and calibration curve is represented in Fig. 3. The curve was obtained with satisfactory a correlation coefficient value of 0.9995 , which indicated a positive correlation between concentrations of favipiravir and the corresponding absorbance values. The method obeyed Beer's law in the range of $0-10 \mu \mathrm{g} / \mathrm{ml}$. Repeatability or intraday precision of favipiravir was $0.408 \%$ and interday precision was within the range of $0.348-$ $0.693 \%$, as shown in Tables 2 and 3. Accuracy was within the range of $99.30-99.91 \%$ (Table 4). Detection limit and quantitation limit are $0.095 \mu \mathrm{g} / \mathrm{ml}$ and $0.290 \mu \mathrm{g} / \mathrm{ml}$, respectively (Table 5). All the findings of favipiravir are mentioned in (Table 6).

\section{CONCLUSION}

It is concluded that the developed UV spectrophotometric method was found to be simple, economic, easy, accurate, precise, linear, specific, and highly sensitive and can be used for routine estimation of favipiravir.

\section{AUTHORS' CONTRIBUTIONS}

The present work was done in collaboration with the two authors, Jeevana Jyothi B and Venkata Kavya R. Both the authors were involved in collection of literature, conducting the experiments, preparation of the manuscript, and contributed equally.

\section{CONFLICTS OF INTEREST}

Declared none.

\section{AUTHORS' FUNDING}

This research received no specific grant from any funding agency.

\section{REFERENCES}

1. Joshi S, Prakar J, Ansari A, Vora A, Talwar D, Tiwaskar M, et al. Role of favipiravir in the treatment of COVID. Int J Infect Dis 2021;102:501-8.

2. Haque SK, Elzagheid M. Antiviral drugs for influenza viruses. Int J Pharm Pharm Sci 2019;11:1-10.

3. Jyothi BJ, Padmaja G. UV spectrophotometric method for estimation of new drug, daclatasvir dihydrochloride. Int Res J Pharm 2016;7:484-8.

4. Bhaskar Reddy CM, Subba Reddy GV. A validated UV spectrophotometric determination of an antiviral drug zanamivir from tablet formulations. J Chem Pharm Res 2018;4:3624-7.

5. Ashour HK, Balel TS. New simple spectroscopic method for determination of the antiviral mixture of emtricitabine and tenofovir disoproxil fumarate. Arab J Chem 2017;10:1741-7.

6. Deepali G, Elvis M. UV Spectrophotometric method for assay of the anti-retroviral agent lamivudine in active pharmaceutical ingredient and in its tablet formulation. J Young Pharm 2010;2:417-9.

7. Pokala RK, Kumari K, Bollikala HK. UV spectrophotometry method development and validation of sulfadiazine and trimethoprim in combined dosage form. Int J Pharm Pharm Sci 2017;10:103-7.

8. Yanjane SA, Ghurghure SM, Matole VK. UV spectrophotometric analysis and validation of oseltamivir phosphate in pure and pharmaceutical formulation. Int J Curr Pharm Res 2020;12:111-4.

9. Sahu SA, Acharya SA, Chourasia AK, Asati AP. Method development and validation of oseltamivir phosphate in bulk drug by UV spectroscopy. Int J Pharm Pharm Sci 2012;4:194-6.

10. Prasanna NL, Rajitha K, Vasundhara G. A rapid and costeffective UV Spectrophotometric method development and validation for the quantitative estimation of indinavir sulphate in capsules. Int J Pharm Pharm Sci 2014;6:504-7. 